\title{
Pengembangan Prototipe Sistem Otomasi Alat Pemberi Makan Ikan Terjadwal Pada Aquarium Berbasis Arduino UNO R3
}

\author{
Dipo Ahmad Harel ${ }^{1}$, Heny Pratiwi ${ }^{2}$, Hendi Hermawan ${ }^{3}$ \\ ${ }^{1}$ Program Studi Informatika, Universitas Pembangunan Jaya, dipo.aharel@student.upj.ac.id \\ ${ }^{2}$ Program Studi Informatika, Universitas Pembangunan Jaya, heny.pratiwi@upj.ac.id \\ ${ }^{3}$ Program Studi Informatika, Universitas Pembangunan Jaya, hendi.hermawan@upj.ac.id
}

\begin{abstract}
At this modern age, society has a fairly solid time. Problems arise when pets have to be left behind because of the owner's business and no time to prepare meals for pets. Therefore, this study was conducted with the aim that animals can still eat according to the schedule and the exact composition in accordance with the weight of the animal. In addition, this tool added a voice notification feature as a marker when the food is up / empty. The main component used in this research is Arduino UNO R3 as the controller and its supporting components are servo where servo is functioning as the closing device and opening the food, humidity sensor to read temperature and humidity in the food room so that can be known from humidity of room that food still good condition or not, result of temperature and humidity will be displayed on LCD, sensor photodiode as a detector of food room is still filled or not, and buzzer as a source of sound for notification if the food in the dining room is up and if the food conditions are not good or moist. The method used in this research is prototype, and test method used is white box and black box method. The result of this research is to build a prototype for one fish with weight 30-45 gram with average food given per day is 1.5 gram
\end{abstract}

Keywords : Scheduled Fish Feeder Equipment, Arduino Uno R3, Fish Feeder Aquarium

\begin{abstract}
Abstrak : Perkembangan teknologi menciptakan ragam pilihan perangkat otomatis yang diciptakan untuk menciptakan kenyamanan pribadi karena terbantu dalam melancarkan aktifitas profesi atau kegemaran. Sistem otomatis sebagai perangkat untuk memberi makan hewan peliharaan secara terjadwal khususnya hewan peliharaan ikan akuarium. Tantangan timbul ketika hewan peliharaan harus ditinggal karena kesibukan pemilik dan tidak ada waktu untuk memberi makan hewan peliharaan. Oleh karena itu, penelitian ini dilakukan dengan tujuan agar hewan tetap dapat makan sesuai dengan jadwal dan komposisi yang tepat sesuai dengan berat badan hewan tersebut serta ditambahkan sebuah fitur notifikasi suara sebagai penanda ketika makanan sudah habis atau kosong. Komponen utama yang digunakan pada penelitian ini adalah Arduino UNO R3 sebagai mikrokontroler pembangun sistem otomasi dan komponen pendukung adalah servo yang berfungsi sebegai alat penutup dan pembuka menuangkan makanan kedalam akuarium, komponen tambahan yang menjadi keunikan penelitian ini adalah sensor kelembaban yang membaca suhu dan kelembaban pada ruang makanan dan selanjutnya mengakibatkan berkurangnya kesegaran makanan ikan tersebut, hasil suhu dan kelembaban akan ditampilkan pada layar LCD, sensor photodioda akan mendeteksi ruang tempat makanan bila masih terisi atau kosong, akhirnya buzzer sebagai notifikasi suara jika makanan sudah habis dan jika kondisi makanan sudah tidak baik untuk dikonsumsi oleh ikan hias
\end{abstract}


akuarium. Metode yang digunakan pada penelitian ini adalah prototipe, dan metode pengujian yang digunakan adalah metode white box dan black box. Sehingga luaran yang dihasilkan dari penelitian ini adalah suatu prototipe pemberi makan ikan untuk satu ikan dengan berat 30 sampai 45 gram dengan rata-rata makanan yang diberikan perharinya adalah 1.5 gram.

Kata Kunci : Alat Pemberi Makan Ikan Terjadwal, Arduino Uno R3, Pemberi Makan Ikan Aquarium.

\section{PENDAHULUAN}

Pemberian makan pada hewan merupakan salah satu bagian terpenting dalam hal untuk memelihara hewan peliharaan. Pemberian makan pada hewan peliharaan cukup penting terutama bagi penggemar ikan sebagai hewan peliharaan, sehingga bisa mengurangi kecemasan akan kondisi terhadap hewan tersebut.

Tidak hanya itu, dalam pengelolaan dan peroses pun juga harus dikerjakan dengan teliti sesuai dengan kondisi ruang lingkup dan kebutuhan hewan, contohnya adalah dalam proses pemberi makan hewan peliharaan, sangat penting jadwal waktu makan, jumlah ukuran makanan, dan kesegaran makanan. Hal tersebut tentu menjadi fokus perhatian bagi pemilik hewan, mengingat hewan peliharaan mudah terserang penyakit jika pola makannya tidak terjadwal dengan baik atau tingkat kesegaran makanan tidak lagi diperhatikan seperti contohnya tertera pada bungkus paket makanan tersebut. Selain menjadi kecemasan bagi pemilik hewan peliharaan, secara umum pemberian makan juga sudah menjadi permasalahan global dengan melihat dari sisi pandang hewan yang berada di berbagai ekosistem dibelahan dunia yang beragam kondisi iklim dan alamnya. Solusi yang beragam juga dapat dilakukan untuk menyelesaikan persoalan pemberian makan hewan peliharaan ini, contoh solusi yang paling mudah, hanya untuk yang bersedia membayar, menitipkan hewan peliharaan tersebut di tempat-tempat pelayanan penitipan hewan. Sedangkan dalam artikel ini, solusi yang diangkat untuk mengatasi masalah pemberian makan hewan peliharaan adalah dengan membangun alat otomatisasi yang berupa alat pemberi makan hewan, otomasi cara alat ini bekerja mengandalkan serangkaian perangkat mikrokontroler. Alat otomasi ini akan sangat berguna bagi pecinta hewan peliharaan untuk penyelia solusi pemberian makan terutama bagi yang memiliki rutinitas pekerjaan dengan jam kerja yang cukup padat.

\section{Rumusan Masalah}

Dari latar belakang yang telah dibahas sebelumnya, maka permasalahan yang dapat dirumuskan adalah bagaimana mengembangkan alat pemberi makan ikan secara otomatis dengan waktu yang terjadwal dan komposisi ukuran yang sesuai dengan berat ikan tersebut, serta kualitas kesegaran makanan yang menjadi keunikan dari sistem ini dibanding dengan yang sudah dirancang bangun sebelumnya.

\section{Tujuan Penelitian}

Tujuan dari penelitian ini adalah untuk mengimplementasikan ilmu pengetahuan yang telah didapat selama di perkuliahan secara dua arah, yaitu pembelajaran literasi dan praktik laboratorium melalui observasi serta eksperimen untuk mewujudkan produk nyata dengan luaran yang tepat guna. Selain itu juga diharapkan akan menjadi salah satu produk yang memberi solusi bagi para pencinta hewan peliharaan ,khususnya ikan hias, dalam pemberian makannya.

\section{KAJIAN PUSTAKA Sistem Otomasi}

Dalam merancang sistem otomasi dibutuhkan data-data tentang karakteristik sebuah rancangan itu sendiri. Sistem 
otomasi pada dasarnya bisa dirancang bangun dimana pengontrol sistem memiliki akses ke sinyal yang dikirimkan oleh masing-masing perangkat sensor yang terpasang dengan lingkup yang sudah diketahui untuk dikendalikan. Setiap perangkat sensor yang terpasang bertugas untuk mendeteksi kondisi fisik tertentu, merespon perubahan dalam kondisi yang dipantau, dan melaporkan kondisi-kondisi tersebut kepada pengontrol sistem. Sementara itu, pengendali sistem merekam dan mempertahankan kondisi tersebut selama pemrosesan. Sehingga pengendali sistem mampu menghasilkan dan terus menerus memperbarui representasi data menurut konteks yang memungkinkan rancangan dan penerapan logika penalaran yang tepat guna dengan logika kondisional (Slupik, 2013).

\section{Mikrokontroler Arduino Uno R3}

Mikrokontroler adalah semacam komputer kecil yang terintegrasi sebagai kesatuan sistem rancang bangun yang terdiri dari mikroprosesor, penyimpan data, dan komponen elektronik sebagai akses masukan dan luaran data.

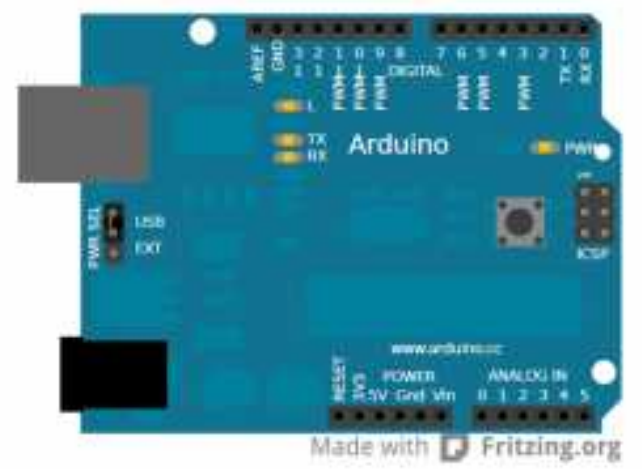

Gambar 1. Mikrokontroler Arduino

Arduino Uno adalah mikrokontroler yang berposisi sebagai open-source. Dilengkapi dengan ATmega328P, empat belas pin input/output, dimana enam dari pin tersebut dapat digunakan sebagai keluaran Pulse Width-Modulation (PWM), enam input analog, satu akses koneksi USB (Universal Serial Bus), Kabel power, dan tombol reset. Untuk mulai melakukan pemprograman, diperlukan pengunduhan perangkat lunak dari link http://arduino.cc/en/Main/Software.

Perangkat lunak ini sudah dikembangkan untuk beradaptasi terhadap elemen-elemen bahasa pemrograman $\mathrm{C}$. Ini adalah alasan bahwa pemakaian Arduino Uno karena pada umumnya telah berisi komponen pendukung sistem minimal mikroprosesor, yakni memori dan pemrograman InputOutput (Santoso, 2013).

\section{METODE PENELITIAN}

Teori metode penelitian ini merujuk teori yang di kemukakan oleh Hanif Priambudi (2017).Teori tersebut mendefinisikan metode untuk merancang prototipe perangkat lunak yang dihasilkan kemudian dipresentasikan kepada klien, dan klien tersebut diberikan kesempatan untuk memberikan masukan dan kritikan, sehingga perangkat lunak/ software yang dihasilkan sesuai dengan kebutuhan dan keinginan klien itu sendiri. Proses ini dapat dilakukan berkali-kali hingga dicapai kesepakatan bentuk dari software yang akan dikembangkan. Namun tahapan pada metode teori prototipe tersebut disesuaikan dengan kebutuhan dalam penelitian ini. Perubahan itu adalah berdasarkan apa yang disebutkan bahwa metode prototype terbagi menjadi enam tahap yaitu tahap pengumpulan data, tahap design, tahap perancangan prototype, tahap evaluasi, tahap penyaringan, dan tahap produksi seperti ditunjukan pada gambar 1 .

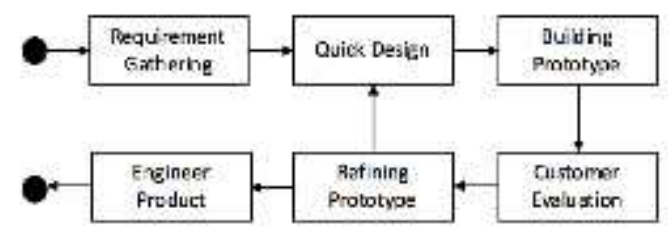

Gambar 2. Metode Prototipe

Pada tahap pengumpulan data dan observasi merupakan tahap pengumpulan data untuk mendukung pekerjaan pembuatan alat. Pada tahap ke-dua yaitu perancangan desain di mana pada tahap ini merupakan tahap desain dari perancangan yang akan dibangun. Lalu pada tahap ke- 
tiga yaitu pembuatan alat otomasi di tahap ini pembangunan alat disesuaikan dengan desain yang sudah dibuat pada tahap sebelumnnya. Pada tahap ke-empat adalah tahap pengujian pada tahap ini akan dilakukan pengujian pada alat yang akan disesuaikan dengan kebutuhan yang kemudian akan dilihat layak atau tidaknya alat tersebut. Jika alat sudah dinyatakan layak maka tahap selanjutnya adalah produksi alat, namun jika alat masih belum layak maka akan ketahap perancangan desain.

\section{ANALISIS \& PERANCANGAN Analisis Sistem Berjalan}

Saat ini bagi para pemelihara ikan kondisi di mana para pemelihara ikan kurang memperhatikan terhadap waktu pemberian pada ikannya. Berikut adalah beberapa referensi terdahulu yang saat ini sudah ada. Pertama, Resun Autofeeder AF 2003 ini di beberapa toko sudah mulai menjual alat otomasi pemberi makan ikan.

Spesifikasi alat dibawah ini seperti yang diambil dari penjelasan deskripsi produk Tokopedia yaitu:

1. Bentuk mini, hemat ruang,

2. Pengaturan cepat dan mudah digunakan,

3. Dapat dioperasikan secara otomatis atau manual dalam pengaturan waktu,

4. Terdapat switch on/off,

5. Waktu pemberian makan dapat diatur pada dua pilihan, yaitu setiap 12 jam atau setiap 24 jam.

6. Ideal untuk berbagai ukuran makanan ikan akuarium.

7. Dioperasikan oleh dua unit baterai ukuran AA.

\section{Spesifikasi Kebutuhan Sistem Baru}

1. Ruang makanan dapat menampung makanan 28,6 gram dan dapat digunakan untuk kebutuhan selama 16 hari.

2. Alat ini hanya untuk satu jumlah ikan dengan ukuran 30-45 gram dengan komposisi makan sehari 1,3 gram.
3. Ruang makanan dikhususkan untuk makanan ikan bentuk pelet kecil.

4. Terdapat sensor humidity yang dapat mendeteksi suhu dan kelembapan pada ruang makanan yang akan dimunculkan pada LCD. sehingga ketika makanan dalam kondisi lembab dan sudah tidak renyah lagi, maka buzzer akan menyala sebagai notifikasi bahwa makanan sudah dalam kondisi tidak baik lagi kualitas kerenyahannya.

5. Terdapat sensor photodioda dimana sensor ini berfungsi sebagai pendeteksi ruang makanan apakah masih terisi atau sudah kosong. Ketika kondisi ruang makan sudah kosong, maka buzzer akan berbunyi sebagai pemberi tanda.

\section{Rancangan Desain Alat}

Pada penelitian ini dirancang sebuah desain alat sebagai purwarupa sebelum perancangan alat dilakukan. Berikut merupakan desain yang telah dirancang. Kotak dari material jenis akrilik berukuran $16 \times 9 \times 6 \mathrm{~cm}$. Kotak tersebut pada sebelah kanan dirancang untuk berfungsi sebagai kotak makanan ikan sedangkan kotak sebelah kiri merupakan kotak tempat pemasangan mikrokontroler Arduino serta komponen lainnya. Pada bagian depan luar kotak terdapat LCD, buzzer, dan switch yang terlihat dari luar. Servo akan berada pada ujung kanan bawah untuk membuka dan menutup tempat keluar makanan.

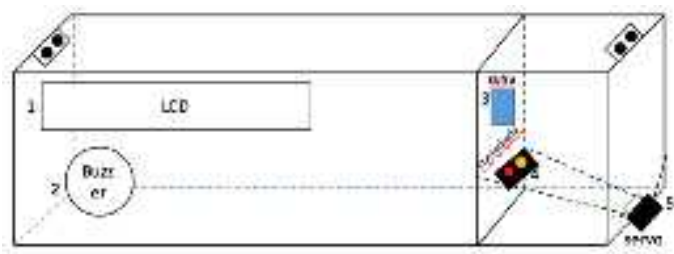

Gambar 3. Rancang Desain Alat

1. Label $1=\mathrm{LCD}$

2. Label $2=$ Buzzer

3. Label $3=$ Switch

4. Label $4=$ Suhu dan humadity

5. Label $5=$ Photodioda

6. Label $6=$ Servo 


\section{Flowchart}

Dibawah ini adalah flowchart operasional sistem yang dibuat, tahap awal dimulai dari inisialisasi alat, setelah insisalisasi alat, kemudian sensor photodioda akan membaca, apakah terdapat makanan pada kotak ruang atau tidak. Jika tidak maka sensor photodioda akan mengirimkan output 0 ke Arduino yang kemudian akan diproses dan dikirimkan lagi perintah oleh Arduino ke buzzer untuk menyala dan akan kembali lagi ke tahap photodioda membaca. Jika sensor photodioda mendeteksi adanya makanan pada ruangan makanan, maka akan dikirimkan output berupa 1 ke Arduino. Setelah itu sensor humidity akan membaca, dan Arduino akan memproses hasil bacaan dari sensor. Hasil pembacaan dari sensor humidity akan ditampilkan pada LCD, jika tingkat kelembaban terbaca lebih dari angka 60, maka Arduino akan mengirimkan sinyal ke buzzer dan buzzer akan berbunyi sebagai notifikasi bahwa kondisi makanan pada ruang makanan sudah tidak baik kulaitas kerenyahannya dan akan kembali lagi ke tahap awal photodioda membaca. Namun, jika ternyata tingkat kelembaban kurang atau sama dengan angka 60, maka counter akan memulai menghitung selama enam jam atau 21600 detik, jika belum mencapai 21600 detik maka counter akan kembali menghitung, namun jika counter sudah menghitung sampai 21600 detik, maka motor servo akan terbuka dengan posisi $90^{\circ}$. Arduino akan memproses dan lanjut ke tahap motor servo, motor servo akan menghitung sampai 10, jika motor servo sudah mencapai hitungan ke 10, maka motor servo akan terbuka dengan posisi $90^{\circ}$ selama 0.5 detik, kemudian motor servo akan tertutup. Proses ini berlanjut dengan penghitungan berbatas empat kali pada proses pembukaan tersebut, jadi sebelum hitungan ke empat, motor servo akan kembali ke awal tahap photodioda membaca, dan tahap selesai pada hitungan ke empat.

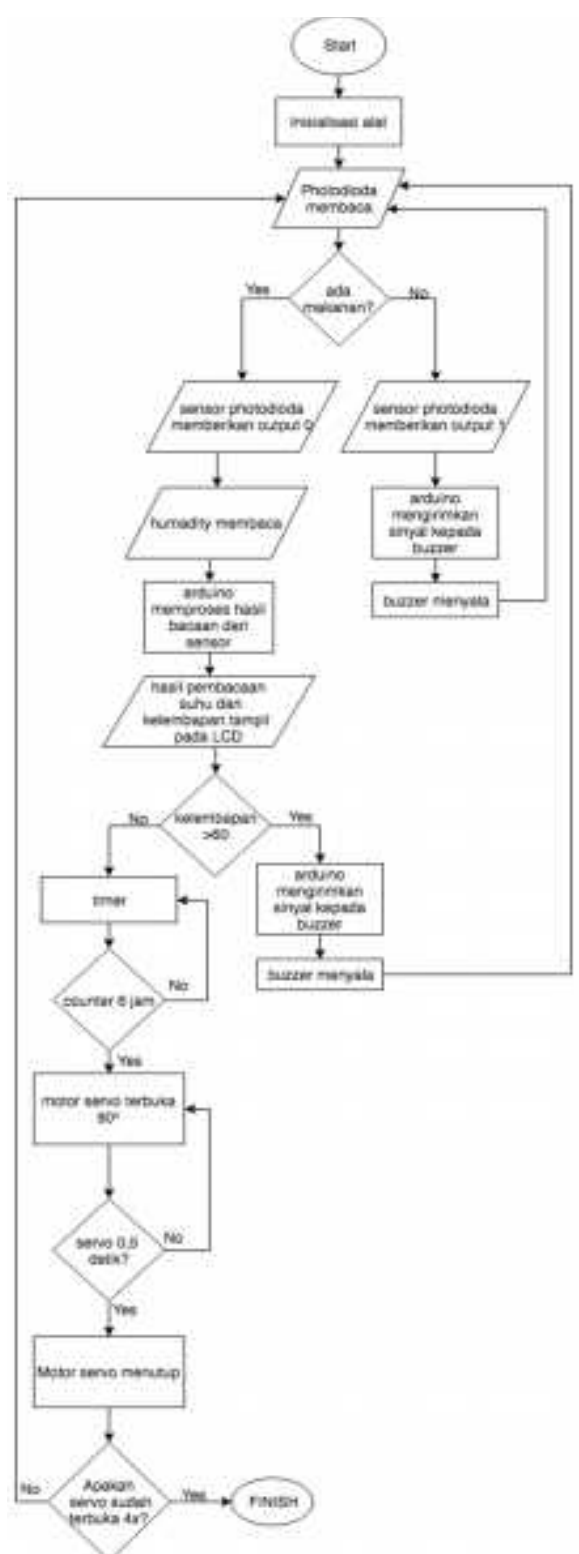

Gambar 4. Flowchart Sistem Otomasi Alat Pemberi Makan Ikan

\section{Blok Diagram}

Blok diagram seperti dibawah ini menunjukan bahwa input yang akan diterima berasal dari sensor photodioda dan sensor kelembaban, kemudian hasil input dari kedua sensor tersebut diproses oleh Arduino dan kemudian output dikirimkan ke LCD dan buzzer.

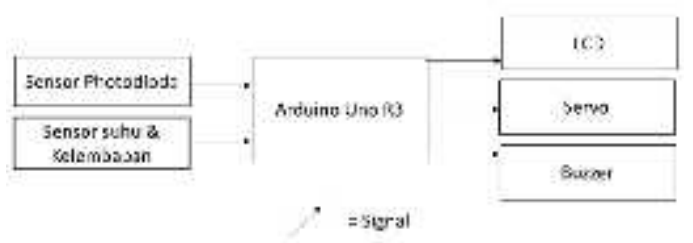

Gambar 5. Blok Diagram Sistem Otomasi Alat Pemberi Makan Ikan 


\section{Skema Rangkaian Alat}

Adapun skema rangkaian alat pemberi makan ikan otomatis ditunjukan seperti gambar 5, sehingga topologi sistem yang dibangun akan lebih mudah dilihat dengan dibantu oleh aplikasi Fritzing.

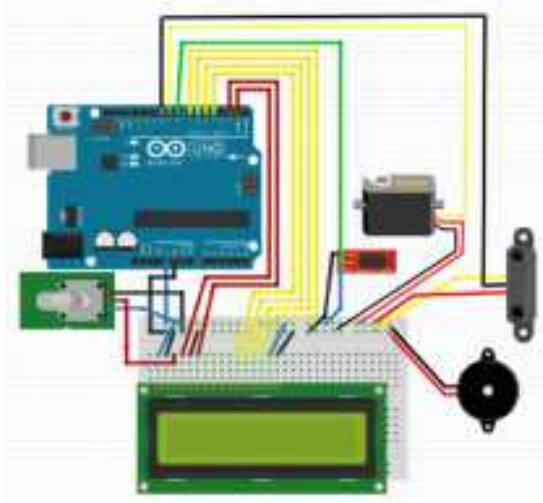

Gambar 6. Skema Rangkaian Alat

\section{HASIL DAN PEMBAHASAN \\ Gambaran Umum Objek Penelitian}

Berawal dari

pemikiran

membangun sebuah sistem otomasi yang dapat memberi makan ikan peliharaan didalam aquarium sesuai dengan waktu, ukuran dan tingkat kesegaran yang telah ditentukan. Selain itu alat ini diharapkan akan mempermudah pemelihara ikan dalam mengontrol ruang makanan ikan terbantukan oleh informasi tentang suhu dan kelembaban pada kotak ruang makan yang tampil pada LCD, sehingga ketika makanan pada ruangan makan ikan sudah mulai menurun jumlahnya, alat ini akan memberikan notifikasi berupa suara. Sehingga objek penelitian ini adalah pada perangkat sistem otomasi itu sendiri. Perangkat sistem otomasi pemberi makan ikan ini diharapkan dapat menjadi solusi bagi pemelihara ikan, terutama ikan hias seperti contohnya ikan maskoki.

\section{Gambaran Umum Subjek Penelitian}

Saat ini pemberian makan ikan masih banyak dilakukan secara manual oleh pemelihara ikan dengan memberi makan secara tidak beraturan dengan menuangkan makanan tanpa memperhatikan frekuensi dan waktu pemberian makan, bahkan terkadang pemelihara ikan yang sibuk dengan aktifitas pekerjaannya atau sering pergi keluar kota sehingga pemelihara ikan kurang memperhatikan skala dan komposisi dalam memberi makan ikan. Peneliti telah merancang solusi untuk permasalahan ini yaitu dengan merancang alat pemberi makan ikan otomatis berbasis Arduino Uno R3 dengan bantuan bberapa komponen perangkat lain seperti sensor humidity dimana sensor ini berfungsi untuk membaca suhu dan kelembaban pada ruang penyimpan makanan, sensor photodioda berfungsi untuk membaca apakah makanan masih ada atau sudah habis, bila terbaca sudah habis kemudian akan mengirim data yanng terbaca sebagai output ke Arduino, kemudian Arduino akan menyambungkan data tersebut ke buzzer sehingga menghasilkan suara, dan yang terakhir adalah servo, dimana servo ini berfungsi untuk membuka dan menutup pintu katup pada ruang penyimpan makanan. Perangkat sistem ini telah dibangun sesuai dengan yang diharapkan.

\section{Hasil Pengujian Alat}

Tabel 1. Tabel Pengujian Makanan

\begin{tabular}{cc}
\hline Percobaan & $\begin{array}{c}\text { Berat Makan ikan } \\
\text { (gram) }\end{array}$ \\
\hline $\mathbf{1}$ & 0,5 \\
$\mathbf{2}$ & 0,6 \\
$\mathbf{3}$ & 0,7 \\
$\mathbf{4}$ & 0,8 \\
\hline
\end{tabular}

Tabel 1 diatas adalah tabel pengujian skala berat makanan yang di keluarkan setiap dua kali motor servo terbuka. Dari hasil pengujian yang telah dilakukan, didapatkan data dengan penghitungan hasil rata-rata adalah 0,65 gram.

Pada Tabel 2, nomor 1 dan 2 merupakan hasil dari tahap pengujian humidity sensor dimana ketika sensor humidity membaca kondisi yang kering maka akan memunculkan hasil kurang dari $60 \%$ dan akan berjalan ke proses selanjutnnya, sebaliknya jika membaca kondisi lembab maka tingkat kelembapan akan menunjukkan lebih dari $60 \%$ dan 
buzzer menyala menghasilkan suara. Lalu pada nomor 3 dan 4 merupakan hasil dari pengujian sensor photodioda, dimana kondisi ruang penyimpan makanan dalam posisi terisi penuh, dalam kondisi seperti ini, indikator buzzer tidak akan berbunyi dan akan memunculkan output 1, sedangkan jika makanan sudah mulai habis, sensor photodioda akan memberikan output 0 ke buzzer dan buzzer akan berbunyi. Dan yang terakhir adalah servo, dimana servo sudah diprogram dengan penghitungan sebanyak 10 , yang membuat servo bergerak terbuka $90^{\circ}$.

Tabel 2. Tabel Pengujian Black Box

\begin{tabular}{|c|c|c|c|c|}
\hline No. & $\begin{array}{l}\text { Skenarin } \\
\text { Pengujian }\end{array}$ & $\begin{array}{l}\text { Hasil yabu } \\
\text { Diharapkean }\end{array}$ & Hasil Pengamatan & Ket: \\
\hline 1 & $\begin{array}{l}\text { Sensor } \\
\text { Hiamidity } \\
\text { dibiarkan } \\
\text { pada nuang } \\
\text { keriag }\end{array}$ & $\begin{array}{l}\text { Memurjukkan sahu } \\
\text { nusngan verta } \\
\text { kelembaban } \\
<-60 \%\end{array}$ & & ss \\
\hline 2 & $\begin{array}{l}\text { Sensor } \\
\text { Humidity } \\
\text { diberikan } \\
\text { tissac } \\
\text { kembab }\end{array}$ & $\begin{array}{l}\text { Menunjulkkan mathu } \\
\text { ruangan verta } \\
\text { kelembapan }>60 \% \text {. }\end{array}$ & & ss \\
\hline 3 & $\begin{array}{l}\text { Sensor } \\
\text { Photodioda } \\
\text { tertutup } \\
\text { makanan } \\
\text { Zan }\end{array}$ & $\begin{array}{l}\text { Memberikan } \\
\text { output } 1 \text { dan } \\
\text { indikator truxzer } \\
\text { tidak berhunyi }\end{array}$ & $\begin{array}{l}\text { Memberikan inpua } 1 \\
\text { dan indikator buszer } \\
\text { tidak berbunyi }\end{array}$ & ss \\
\hline 4 & $\begin{array}{l}\text { Senser } \\
\text { Photodioda } \\
\text { tidak } \\
\text { tertutus } \\
\text { makanan } \\
\text { Ran } \\
\end{array}$ & $\begin{array}{l}\text { Memberikan } \\
\text { otriput } 0 \text { dan } \\
\text { indikator truzker } \\
\text { berbunyi }\end{array}$ & $\begin{array}{l}\text { Mersberikan inpus } 0 \\
\text { dan indikatar buzzer } \\
\text { berbunyi }\end{array}$ & ss \\
\hline 5 & $\begin{array}{l}\text { Servo điberi } \\
\text { eouter } 10 \\
\text { dengan } \\
\text { posisi akhir } \\
\text { 90 }\end{array}$ & $\begin{array}{l}\text { Servo } \\
\text { bergenkinkenbuka } \\
\text { sebesat } 90^{\circ} \text { setiap } \\
10 \text { detik sekali }\end{array}$ & $\begin{array}{l}\text { Servo } \\
\text { bergerak/merabuka } \\
\text { sebesar } 90 \text { derajat } \\
\text { setiap } 10 \text { detik sekali }\end{array}$ & Ss \\
\hline 6 & $\begin{array}{l}\text { Serve tanpa } \\
\text { baetuan } \\
\text { penyzaggah }\end{array}$ & Makanas keluar & $\begin{array}{l}\text { Makaranan tidak } \\
\text { kelias }\end{array}$ & BS \\
\hline 7 & $\begin{array}{l}\text { Servo } \\
\text { dengan } \\
\text { bastuan } \\
\text { penyanggah }\end{array}$ & Makanas keluar & Makanan Kcluar & ss \\
\hline
\end{tabular}

\section{KESIMPULAN}

Dari hasil pembahasan di atas dapat diambil beberapa kesimpulan sebagai berikut:

a) Telah dilakukan perakitan perangkat keras sesuai dengan analisis dan perancangan yang dilakukan dengan menggunakan mikrokontroler Arduino UNO R3, dan dibantu dengan komponen sensor photodioda, sensor suhu dan kelembapan, dan LCD.

b) Alat berjalan dengan baik sesuai dengan yang dirancang, sehingga komposisi makanan yang keluar dari alat sudah sesuai dengan yang ditargetkan, makanan yang keluar dari penyimpan makanan tertuang kedalam aquarium sesuai waktu dan kualitas kesegaran yang ditargetkan.

\section{DAFTAR PUSTAKA}

1. Slupik, S., Automation and Control System with Inference and Anticipation, United States Patent Publication No.: US2015/0192914 A1 Pub. Date: Jul.9, 2015

2. Ari Beni Santoso, Pembuatan Otomasi Pengaturan Kereta Api, Pengereman, dan Palang Pintu Pada Rel Kereta Api Mainan Berbasis Mikrokontroler, Jurnal FEMA, ,Vol. 1, Januari 2013

3. Ecadio, Mengenal Arduino Uno R3, diunduh pada tanggal 18 Mei 2018 dari http://ecadio.com/mengenal-danbelajar-arduino-uno-r3

4. Hanif Priambudi, Pengertian Metode Prototype, Tahapan dan Kelebihan Metode Prototype, diunduh pada tanggal 16 Mei 2018 dari https://androidunik.com/pengetahuan/ pengertian-metode-prototype-dankelebihannya/

5. Mahadisuta, Pengujian White Box dan Black Box Wajib Dilakukan Seseorang Developer, diunduh pada tanggal 18 Mei 2018 dari https://www.mahadisuta.com/artikel/5 a1f5eb584545/pengujian-white-boxdan-black-box-wajib-dilakukanseorang-developer 